\title{
Societies within peace systems avoid war and build positive intergroup relationships
}

Douglas P. Fry (10 ${ }^{1 凶}$, Geneviève Souillac ${ }^{1}$, Larry Liebovitch (10 ${ }^{2}$, Peter T. Coleman ${ }^{3}$, Kane Agan ${ }^{4}$, Elliot Nicholson-Cox ${ }^{4}$, Dani Mason ${ }^{4}$, Frank Palma Gomez ${ }^{2} \&$ Susie Strauss ${ }^{4}$

A comparative anthropological perspective reveals not only that some human societies do not engage in war, but also that peaceful social systems exist. Peace systems are defined as clusters of neighbouring societies that do not make war with each other. The mere existence of peace systems is important because it demonstrates that creating peaceful intergroup relationships is possible whether the social units are tribal societies, nations, or actors within a regional system. Peace systems have received scant scientific attention despite holding potentially useful knowledge and principles about how to successfully cooperate to keep the peace. Thus, the mechanisms through which peace systems maintain peaceful relationships are largely unknown. It is also unknown to what degree peace systems may differ from other types of social systems. This study shows that certain factors hypothesised to contribute to intergroup peace are more developed within peace systems than elsewhere. A sample consisting of peace systems scored significantly higher than a comparison group regarding overarching common identity; positive social interconnectedness; interdependence; nonwarring values and norms; non-warring myths, rituals, and symbols; and peace leadership. Additionally, a machine learning analysis found non-warring norms, rituals, and values to have the greatest relative importance for a peace system outcome. These results have policy implications for how to promote and sustain peace, cohesion, and cooperation among neighbouring societies in various social contexts, including among nations. For example, the purposeful promotion of peace system features may facilitate the international cooperation necessary to address interwoven global challenges such as global pandemics, oceanic pollution, loss of biodiversity, nuclear proliferation, and climate change.

\footnotetext{
${ }^{1}$ University of North Carolina at Greensboro, Greensboro, NC, USA. ${ }^{2}$ City University of New York, New York, NY, USA. ${ }^{3}$ Columbia University, New York, NY, USA. ${ }^{4}$ University of Alabama at Birmingham, Birmingham, AL, USA. ${ }^{凶}$ email: dpfry@uncg.edu
} 


\section{Introduction}

recurring assumption is that all societies engage in war (Wilson, 2001; Wright, 1942). However, anthropological data show that this is not the case (Fry, 2006; Montagu, 1978; Sponsel, 2018; Souillac and Fry, 2014, 2015). In some cases, non-warring societies are organised into peace systems, defined as clusters of neighbouring societies that do not make war with each other, and sometimes not at all (Fry, 2006; 2012; Souillac and Fry, 2015). An ethnographically comparative view suggests that over time reciprocal prosocial relationships develop and link the nonwarring societies within a larger common social system wherein cooperation and unity prevail and war among the members simply becomes unfathomable. For example, the Nordic Nations have not warred among each other for over 200 years as they developed "the concept of social peace based on a culture of conflict resolution and societal solidarity" (Archer, 2003: p. 16). Over time, the Nordic nations evolved a propensity for peace and strengthened non-warring values that favour negotiation, cooperation, and the rule of law. Many times, wars could have been fought, but were not, such as when Norway gained independence from Sweden in 1905 without firing a shot or during a dispute between Finland and Sweden over the Åland Islands (see Fig. 1). The Nordic nations set-up overarching institutions such as the Nordic Council to address common concerns, and an overarching Nordic identity emerged (Archer, 2003).

We propose that gaining an understanding of how peace systems develop and how they function without war holds important implications for promoting positive, cooperative inter-societal relationships in a variety of other social contexts, including within regional and global spheres. Compared to scientific advances in many areas, we know surprisingly little about the overarching dynamics and principles through which human societies build and maintain peaceful relations. Therefore, we sought to explore how societies operating within non-warring peace systems sustain peace. We tested whether certain factors hypothesised to contribute to intergroup peace were in fact more developed within peace systems than elsewhere. The research also employed a machine learning technique called Random Forest to assess the relative importance of the hypothesised peace variables. Investigating which processes recur across socially disparate, and geographically diverse, non-warring systems may contribute both to basic knowledge and to practical applications for facilitating

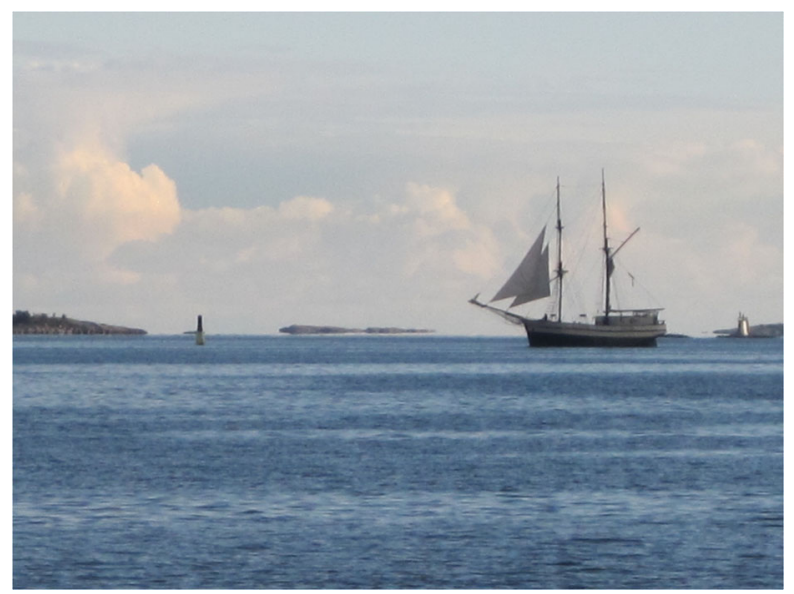

Fig. 1 The five Nordic Nations, Norden, have not engaged in war with one another since 1815. A dispute between Finland and Sweden over the strategically located Åland Islands was resolved through mediation. The Åland Islands remain a demilitarised and neutral area. Reproduced with permission of Douglas P. Fry; copyright (c) Douglas P. Fry, all rights reserved. peaceful relationships among societies. A scientific understanding of how societies within peace systems cooperatively and prosocially interact in the absence of war has policy implications for promoting the collaboration necessary to meet overarching challenges such as climate change or pandemics within an interdependent global system.

Anthropology shows that peace systems can be found in different parts of the world and at various levels of social organisation. Anthropological and historical descriptions of nonwarring social systems include Australian Aborigines of the Great Western Desert, mobile foragers of Canada's Labrador Peninsula, tribes of Brazil's Upper Xingu River basin, the Iroquois Confederacy, the Swiss cantons that unified into Switzerland in 1848, and the United States since 1865, among others (Dennis, 1993; Fry, 2006, 2009, 2012; Gregor, 1994; Hendrickson, 2003; Parent, 2011; Souillac and Fry, 2015). When speaking of peace systems as lacking warfare, we are defining war as "relatively impersonal lethal aggression between communities," a definition of intergroup violence that applies across social types from bands and tribes to kingdoms and nations (Fry, 2006: p. 91).

A consideration of the theoretical literature and ethnographic descriptions suggests that various factors contribute to intersocietal peace (Archer, 2003; Cronin, 1999; Fry, 2012; Nowak et al., 2012; Parent, 2011; Rubin et al., 1994; Souillac, 2020). There are archaeological indications of peace systems in prehistory (Ferguson, 2013; Fry, 2012; Haas, 1999) and ethnographic and historical descriptions of non-warring social systems, but the peace system concept has only recently taken shape. Gregor (1994) applied the term peace system to ten neighbouring tribes, representing four different language groups, from the Upper Xingu River region of Brazil wherein "the politically autonomous tribes act somewhat like linguistically distinct and residentially separate ethnic groups within a larger social framework of common institutions and values" (Gregor, 1994: p. 244). Gregor $(1990,1994)$ proposed that the interdependent relationships in trade among the tribes, the patterns of intermarriage, participation in common rituals and ceremonies, and the strong anti-war values taught to each new generation combine to keep this system self-sustaining.

Fry $(2009,2012)$ expanded the peace system construct conceptually and geographically beyond the Upper Xingu case by providing descriptions of the Iroquois Confederacy, Aboriginal Australia, and the European Union as additional peace systems. For example, prior to the formation of the Iroquois Confederacy, the original five member tribes, the Seneca, Cayuga, Onondaga, Oneida, and Mohawk, were locked into chronic warring and feuding (Dennis, 1993; Fenton, 1998; Fry, 2012). The Iroquoian peoples developed a new overarching identity in addition to their tribal identities, which they expressed metaphorically as five related families living in harmony in the same longhouse (see Fig. 2; Fenton, 1998). They expanded the tried-and-true institutions of the village council and tribal council to create the new higher-level institution, the Council of Chiefs, as an intertribal mechanism of governance and conflict management based on discussion and consensus (Dennis, 1993; Fenton, 1998). Peace values and norms were reinforced by narratives, symbols, and rituals, such as through the legend of the Peacemaker bringing tranquility and unity to the five tribes and the enactment of unifying condolence rites (Dennis, 1993; Fenton, 1998; Fry, 2012). Are such features generally found in peace systems?

\section{Peace system hypotheses}

We hypothesise multiple contributors to peace (Fry, 2012; Nowak et al., 2012; Souillac, 2012; Souillac and Fry, 2015). Drawing on 


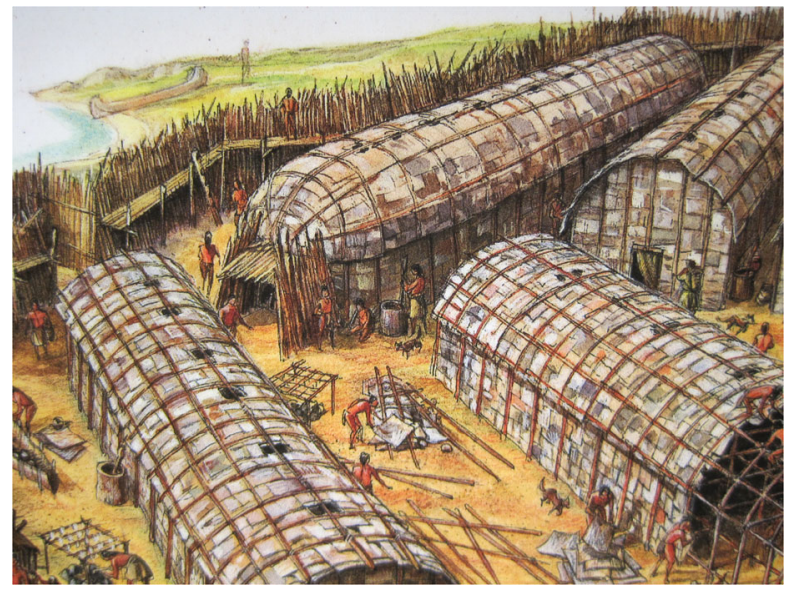

Fig. 2 An Iroquois village showing longhouses. The member tribes of the Iroquois Confederacy, which lasted over 300 years, gave up warring with one another. The revered peacemaker-prophet named Diganawidah is reputed to have drawn an analogy between the families of a longhouse living harmoniously under one shared roof and the tribes of the confederacy living in unity and peace under the law. Reproduced with permission of Douglas P. Fry; copyright (c) Douglas P. Fry, all rights reserved.

ethnographic data from the Upper Xingu peace system (Gregor, 1990, 1994; Ireland, 1986), the Iroquois Confederacy (Dennis, 1993; Fenton, 1998), the peaceable societies of peninsular Malaysia (Dentan, 2004; Endicott, 2017; Endicott and Endicott, 2008; Howell, 1989), the non-warring neighbours of the Nilgiri Hills in India (Rivers, 1986; Walker, 1986), the European Union (Bellier and Wilson, 2000; Hill, 2010; Staab, 2008), and other cases, Fry (2012) hypothesised that multiple factors promote peace within dynamic peace systems. These include (1) an overarching common identity in addition to local identities, (2) a high degree of prosocial interconnectedness among the social units within a system, (3) interdependence among the social units, (4) core values and norms that are non-warring and peace favouring, (5) narratives, rituals, ceremonies, and symbols that reinforce peaceful values, norms, beliefs, and conduct, (6) superordinate institutions, (7) mechanisms for nonviolent intergroup conflict management, and (8) visionary peace leadership (Fry, 2009, 2012; Souillac and Fry, 2015; Souillac, 2020). This list of hypothesised peace-related factors stems both from case studies of peace systems and from a diverse set of social science studies on intergroup conflict and peacemaking (Coleman and Deutsch, 2012; Dennis, 1993; Dovidio et al., 2000; Fry, 2006; Goldschmidt, 1994; Gregor, 1994; Parent, 2011; Rubin et al., 1994; Schirch, 2014; Souillac, 2020). In this study, we compared statistically a group of ethnographically and historically described peace systems with a randomly derived comparison group regarding the above peace hypotheses and also regarding several war-related variables (e.g., war norms and values and war leadership) predicted to be less manifested within peace systems.

\section{Methods}

Samples. We sought peace systems in the anthropological and historical literature to compare with a sample of non-peace systems regarding various features hypothesised to promote dynamic peace among neighbouring social units (Fry, 2012). We were able to locate 16 well-documented examples of peace systems in the literature that comprise the experimental sample. Undoubtedly, additional peace systems exist and will be uncovered in the future.

The task of finding clusters of neighbouring societies that do not make war with each other is complicated by the paucity of scholarly attention that has been paid to this phenomenon. Since, our research group operationally defined peace systems for the first time (Fry, 2009, 2012; Souillac and Fry, 2015), there was no catalogue, list, or database of known peace systems before we began this line of research. The cases located represent different levels of social organisation (e.g., bands, tribes, nations) across a world-wide distribution and include nearly all known anthropological examples of peace systems (Supplementary Table S1 online).

Extracting data for each peace system and comparison case from the literature is a time-consuming process. The location of sources, careful review of the material, and coding of each case is labour intensive, which also limits the sample size due to practical considerations. An implication of small sample size is that some of the results may reflect type two errors, for example, regarding the non-significant differences for intermarriage as a form of interconnectedness or conflict management overall.

To derive a geographically diverse comparison group of nonpeace systems, cases were randomly derived from the Standard Cross-Cultural Sample (SCCS) in order to focus on the selected societies and their adjacent neighbours (Murdock and White, 1969, 2006; White, 1989). The SCCS represents 186 cultural provinces from around the world and various types of societies (White, 1989). The range of SCCS case numbers-that is, from 1 to 186 to represent each case number in the SCCS-was entered as the sampling pool into an online random number generator (Haarh, 2020). Our target number for the comparison sample was at least 30 to balance a reasonable number of cases against the labour-intensive coding process for each case, and we generated a list of 33 randomly selected cases from the SCCS. Any duplicate occurring random numbers were simply tossed out and a new number generated to represent a novel society from the pool. If a randomly generated case represented one of the known peace systems, it was also eliminated and replaced by a newly generated random number. We over-sampled by three cases with the idea that a few of the key bibliographic sources might prove to be unavailable or only available in a non-English language. In fact, such constraints reduced the original randomly derived comparison cases from 33 to 30, as listed in Supplementary Table S2 online.

Procedure. A coding sheet (see Supplementary Information online) was designed for use in scoring the entire sample of 46 cases (peace systems and non-peace systems) regarding variables hypothesised to contribute to peaceful relationships among neighbouring social units (Ember and Ember, 2001). The list of hypothesised features that contribute to the origin and maintenance of peace systems consisted of those features listed in Fry (2012), plus a new variable on visionary peace leadership. Additionally, several variables that focused on war were included for comparative purposes.

For each peace system in the sample, we developed a bibliography of cultural sources to use for coding. The peace system reference citations are included in the Supplementary Information online as bibliographies for each system. For the cases in the non-peace system comparison sample, we reviewed the ethnographic material ranked by White (1989) in the SCCS bibliography as principal authority sources (PAS), meaning that these are high-quality primary sources. We used only the PAS listed in White's (1989) bibliography to acquire the relevant information on each non-peace system case (Supplementary Table S2 online).

Statistical analyses. Coded data were entered into a numerical database (Supplementary Information online, Data file). 
Correlations and Mann-Whitney $U$-tests were run using IBM's Statistical Package for the Social Sciences (SPSS), version 26.0 (IBM, 2019). Since correlations involve ordinal variables and small group sizes, the reported $p$-values are for Kendall's Tau statistic. Since normality could not be assumed for the variables in this relatively small sample, Mann-Whitney $U$-tests were considered more appropriate (and conservative) than Student's $t$-tests for comparing the two sub-samples. Missing values were replaced by mean values in SPSS.

The data science classification algorithm called Random Forest was used to assess the relative importance of variables hypothesised to contribute to peace. Random Forest is a supervised machine learning method that can be used to determine the relative importance of different variables in reaching a classification decision, in this case to separate peace systems from non-peaceful systems (Raschka and Mirjalili, 2017; Yiu, 2019). During a training phase, Random Forest constructs many individual decision trees. The process uses a randomly selected subset of the data and variables to construct this "random forest" of decision trees. The using of different subsets of the data and different variables to generate individual trees increases the variation among trees in the ensemble. The prediction from the individual decision trees are then pooled for making a final prediction about the relative importance of variables. The combined decision trees constituting this Random Forest has the capacity to make more accurate predictions than any individual decision tree alone. The procedure also ensures that the final Random Forest does not overfit the original training set. We used the Random Forest classifier from the scikit-learn python library (Pedregosa et al., 2011) with the parameter that specifies the number of the decision trees, "n estimators," set to 2000 and the initial random seed set to "random_state=42." After the classifier was trained, we used the "feature_importances" attribute to extract the importance score for each peace-related variable, which allows the ranking of the variables as to their relative importance for a peace system outcome. We applied the machine learning analysis to all the peace-related variables that showed statistically significant differences between the two samples by Mann-Whitney $U$-tests and included one additional variable that showed only a non-significant trend in the predicted direction, overarching governance, to have at least one variable represented in the analysis for each of the eight hypothesised peace system features.

\section{Results}

We first ran correlation analyses across the entire sample and found many significant correlations among the eight features hypothesised to be elements of dynamic peace systems (Table 1). All significant correlations among peace-related variables were positive. Common overarching identity and interconnectedness were positively correlated with all seven other peace system variables. On the other hand, all significant correlations between peace variables and war variables were negative. We found some of the strongest negative correlations between peace norms and values, peace myths, rituals, and symbols, and peace leadership, on the one hand, and war norms and values, war myths, rituals, and symbols, and war leadership on the other. Finally, with the partial exception of ethnocentrism, war features were found to be positively correlated with each other.

To address whether the features hypothesised to be important elements of peace systems were manifested to a greater extent within peace systems than within non-peace systems, we ran twosample Mann-Whitney $U$-tests (Table 2). Inaccordance with sixout-of-eight of the main predictions, the peace system sample scored significantly higher than the non-peace system sample for overarching identity; positive interconnectedness; interdependence; non-warring values and norms; non-warring myths, rituals, and symbols; and peace leadership. The two variables superordinate institutions and nonviolent conflict management overall were not significantly different between the samples. By contrast, non-peace systems scored significantly higher for warring values and norms; war myths, rituals, and symbols; and war leadership. Ethnocentrism was not significantly different between the samples.

We also performed a more granular analysis (Table 3 ). When four measures of prosocial interconnectedness (intermarriage, trade, politics, and positive history) were analysed separately, only economic and historical interconnectedness were significantly greater in peace systems than in non-peace systems, although intermarriage approached significance. All three subtypes of interdependence (security, ecological, and economic) were significantly greater in the peace system sample than in the comparison sample, with economic interdependence being highly significant. When non-warring values and non-warring norms were disaggregated for separate analysis, both variables were found to be significantly more pronounced in peace systems than in non-peace systems. Finally, when we analysed the three subelements of non-warring myths, rituals, and symbols separately, peace rituals and symbols turned out to be significantly different between the two samples, but peace myths were not.

To address the question of which hypothesised variables were relatively more important contributors to peace, we employed the machine learning technique called Random Forest. We found that the most important contributing factor to a peace system outcome was the existence of non-warring norms, followed in order of decreasing importance by non-warring rituals, non-warring values, security interdependence, and so forth (Table 4). Thus, the Random Forest analysis provided a method for ranking the relative importance of the peace-related variables for leading to a peace system outcome as opposed to a non-peace system outcome.

\section{Discussion}

Peace systems research challenges the assumption that societies everywhere are inclined to make war with their neighbours. Science-based understanding of how peace systems emerge and are maintained may have implications for creating and promoting peace and cooperation in various contexts, whether within a nation, among nations, regionally, or globally (Coleman and Deutsch, 2012; Fry, 2012). Our findings demonstrate that peace systems, defined behaviourally as clusters of neighbouring societies that do not make war on each other, differ on a variety of dimensions from societies that are not part of such social systems. We found most of the main hypothesised peace contributors to be present to a greater degree in peace systems than in a randomly selected comparison sample across various levels of social complexity. This suggests there are recurring features that can contribute to the development and maintenance of non-warring relationships among societies. Consequently, an analysis of peace systems may offer transferable insights about how to promote prosocial, cooperative inter-societal relations at various levels of social organisation.

When the eight peace-related hypotheses were partitioned into more granular predictions, differences between the peace systems and the comparison sample were significant for economic and positive historical interconnections but not for intermarriage and political interconnections. Both non-warring norms and non-warring values were significant, as were peace rituals and symbols. Peace rituals and symbols may reflect and reinforce core values and norms (Dennis, 1993; Gregor, 1994; Schirch, 2014). 
Table 1 Correlations among peace-related and war-related variables.

\begin{tabular}{|c|c|c|c|c|c|c|c|c|c|c|c|c|}
\hline & 1 & 2 & 3 & 4 & 5 & 6 & 7 & 8 & 9 & 10 & 11 & 12 \\
\hline \multicolumn{13}{|l|}{ Peace-related } \\
\hline 1. Overarching Identity & 1 & $0.361^{a}$ & $0.265^{c}$ & $0.288^{c}$ & $0.288^{c}$ & $0.298^{c}$ & $0.290^{c}$ & 0.094 & $-0.251^{c}$ & -0.204 & -0.056 & -0.172 \\
\hline 2. Interconnected-ness & & 1 & $0.489^{a}$ & $0.367^{a}$ & $0.360^{a}$ & $0.363^{b}$ & $0.345^{a}$ & $0.353^{b}$ & $-0.300^{b}$ & $-0.220^{c}$ & $-0.235^{c}$ & -0.176 \\
\hline 4. Non-warring values and norms & & & & 1 & $0.434^{a}$ & 0.078 & 0.105 & $0.372^{b}$ & -0.204 & $-0.568^{a}$ & $-0.572^{a}$ & $-0.433^{a}$ \\
\hline $\begin{array}{l}\text { 5. Non-warring myths, rituals, and } \\
\text { symbols }\end{array}$ & & & & & 1 & 0.168 & 0.193 & $0.341^{b}$ & $-0.305^{b}$ & $-0.470^{a}$ & $-0.350^{b}$ & $-0.373^{b}$ \\
\hline 8. Peace leadership & & & & & & & & 1 & -0.231 & 0.212 & $-0.335^{b}$ & $-0.296^{c}$ \\
\hline \multicolumn{13}{|l|}{ War-related } \\
\hline 9. Ethnocentrism & & & & & & & & & 1 & $0.255^{c}$ & 0.176 & 0.167 \\
\hline 10. Warring values and norms & & & & & & & & & & 1 & $0.492^{\mathrm{a}}$ & $0.492^{\mathrm{a}}$ \\
\hline 11. War myths, rituals, and symbols & & & & & & & & & & & 1 & $0.369^{b}$ \\
\hline 12. War leadership & & & & & & & & & & & & 1 \\
\hline
\end{tabular}

Table 2 Peace systems and non-peace systems compared regarding the primary peace-related and war-related variables.

\begin{tabular}{|c|c|c|c|c|c|}
\hline \multirow[t]{2}{*}{ Variables } & \multicolumn{2}{|c|}{$\begin{array}{l}\text { Peace systems } \\
(n=16)\end{array}$} & \multicolumn{2}{|c|}{$\begin{array}{l}\text { Non-peace systems } \\
(n=30)\end{array}$} & \multirow[t]{2}{*}{ Significance } \\
\hline & Mean & SD & Mean & SD & \\
\hline Overarching Identity ${ }^{a}$ & 3.06 & 0.792 & 2.25 & 0.745 & $p=0.003$ \\
\hline Interconnectedness ${ }^{\mathrm{a}}$ & 3.03 & 0.496 & 2.49 & 0.524 & $p=0.000$ \\
\hline Interdependence ${ }^{a}$ & 3.01 & 0.642 & 2.33 & 0.603 & $p=0.003$ \\
\hline Superordinate institutions ${ }^{a}$ & 2.91 & 1.39 & 2.47 & 0.708 & $p=0.064 \mathrm{~ns}$ \\
\hline Conflict management ${ }^{a}$ (All types together) & 2.78 & 0.467 & 2.55 & 0.193 & $p=0.093 \mathrm{~ns}$ \\
\hline Peace leadershipa & 3.05 & 0.903 & 2.61 & 0.551 & $p=0.019$ \\
\hline \multicolumn{6}{|l|}{ War-related } \\
\hline Ethnocentrisma & 2.36 & 0.546 & 2.73 & 0.611 & $p=0.082 \mathrm{~ns}$ \\
\hline Warring values $\&$ norms ${ }^{a}$ & 1.93 & 1.036 & 2.97 & 0.547 & $p=0.002$ \\
\hline War myths, rituals, \& symbols ${ }^{b}$ & 2.03 & 0.622 & 2.54 & 0.413 & $p=0.003$ \\
\hline
\end{tabular}

For example, rituals and symbols of peace are manifested in the Iroquois legend of Deganawidah, the visionary peacemaker who unified the tribes and symbolically buried their weapons of war under the great tree of peace (Fenton, 1998; Fry, 2012).

Non-warring norms and values stand out as having the highest mean scores across the peace-related variables within peace systems. Non-warring norms and values are evident, for example, in the Upper Xingu view that aggression is immoral (Gregor, 1994; Ireland, 1986), the Malaysian Orang Asli peoples emphasis on nonviolent socialisation of children (Dentan, 2004; Endicott, 2017; Howell, 1989), the Nordic value placed on consensus decision-making and peacebuilding (Archer, 2003), and so forth (Fry, 2006; Souillac and Fry, 2014, 2015).
No significant difference between the groups was found for the hypotheses pertaining to superordinate institutions and conflict management generally. However, the superordinate institutions hypothesis may apply primarily at more complex levels of social organisation, as contrasted with bands and tribes, and was not detectable in this socially heterogeneous sample (see Supplementary Table S1 online). This topic deserves further investigation.

Turning to war variables, predictably, peace systems exhibited significantly weaker warring values and norms; warring myths, rituals, and symbols; and war leadership than found in the nonpeace system sample. Although negatively correlated, peacerelated and war-related variables are not mutually exclusive; 
Table 3 Peace systems and non-peace systems compared regarding the subcomponents of interconnectedness, interdependence, non-warring values and norms, and peace myths, peace rituals, and peace symbols.

\begin{tabular}{|c|c|c|c|c|c|}
\hline \multirow[t]{2}{*}{ Variable } & \multicolumn{2}{|c|}{$\begin{array}{l}\text { Peace systems } \\
(n=16)\end{array}$} & \multicolumn{2}{|c|}{$\begin{array}{l}\text { Non-peace system } \\
(n=30)\end{array}$} & \multirow[t]{2}{*}{ Significance } \\
\hline & Mean & SD & Mean & SD & \\
\hline Marriage $^{a}$ & 2.72 & 0.806 & 2.27 & 0.766 & $0.060 \mathrm{~ns}$ \\
\hline Economic $^{a}$ & 3.47 & 0.719 & 2.73 & 0.905 & 0.002 \\
\hline Politicala & 2.64 & 1.183 & 2.26 & 0.616 & 0.691 ns \\
\hline Security ${ }^{a}$ & 2.84 & 1.363 & 2.32 & 0.737 & 0.050 \\
\hline Ecological ${ }^{\mathrm{a}}$ & 2.91 & 0.917 & 2.28 & 0.727 & 0.028 \\
\hline Economic ${ }^{a}$ & 3.27 & 0.739 & 2.38 & 0.739 & 0.002 \\
\hline \multicolumn{6}{|c|}{ Non-warring values $\&$ norms } \\
\hline Values ${ }^{a}$ & 3.64 & 0.710 & 2.92 & 0.753 & 0.001 \\
\hline Norms ${ }^{a}$ & 3.70 & 0.584 & 2.75 & 0.726 & 0.000 \\
\hline \multicolumn{6}{|c|}{ Non-warring myths, rituals, $\&$ symbols } \\
\hline
\end{tabular}

\begin{tabular}{|c|c|}
\hline Peace-related variable & $\begin{array}{l}\text { Random forest } \\
\text { importance score }\end{array}$ \\
\hline Non-warring norms & 0.213 \\
\hline Non-warring rituals & 0.110 \\
\hline Non-warring values & 0.095 \\
\hline Security interdependence & 0.094 \\
\hline Superordinate institutions & 0.080 \\
\hline Economic interdependence & 0.077 \\
\hline Positive historical Interconnectedness & 0.074 \\
\hline Peace leadership & 0.053 \\
\hline Economic interconnectedness & 0.052 \\
\hline Overarching identity & 0.050 \\
\hline Ecological interdependence & 0.046 \\
\hline Peace symbols & 0.029 \\
\hline $\begin{array}{l}\text { Conflict management (specifically via } \\
\text { intergroup moots, councils, or meetings) }\end{array}$ & 0.028 \\
\hline
\end{tabular}

various degrees of peace and war leadership, for example, may coexist (Fenton, 1998; Goldschmidt, 1994). However, the findings show that peace systems more strongly exhibit peace norms and values than war norms and values, whereas the opposite is the case for the comparison group.

The eight main peace-related variables exhibited a high degree of positive correlation with each other. From the sources describing peace systems, the bundling of peace attributes is expressed in many ways. For instance, allusion to rituals, overarching institutions, peace leadership, interconnectedness, and security interdependence appear in this passage on the Iroquois: "Initiating new rituals and practices, and inventing new social and political institutions, the prophet Deganawidah and those who followed his teachings found ways to assure domestic concord, to extend harmony within longhouses, lineages, and clans to wider domains, and to confront the ever-present threats to stability,

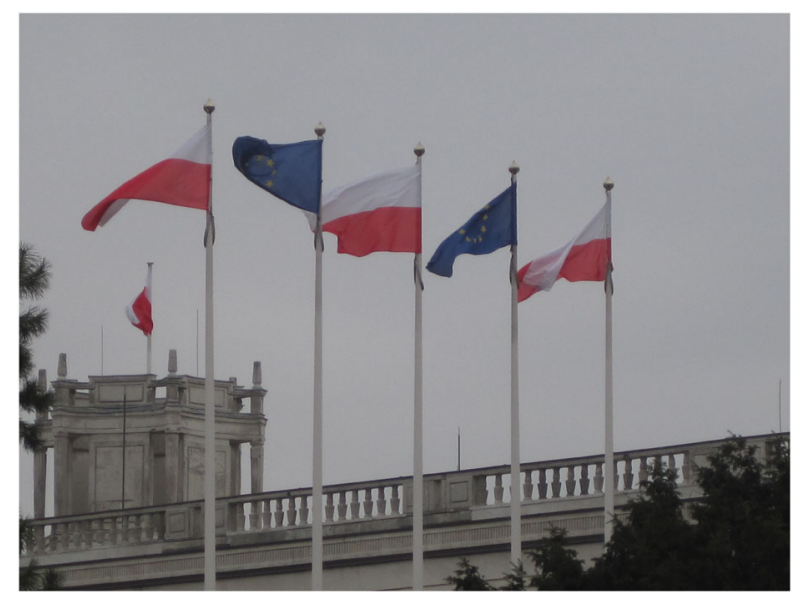

Fig. 3 Polish and European Union flags fly side-by-side in Warsaw, symbolising the dual national and supranational identities within the European peace system. The development of an overarching socio-political identity is a notable feature of peace systems. Reproduced with permission of Douglas P. Fry; copyright (c) Douglas P. Fry, all rights reserved.

reason, and peace" (Dennis, 1993: p. 77). Overarching identity, such as belonging to "one country," being kin, or becoming "one people," recur in descriptions of peace systems (see Fig. 3). Correspondingly, Dovidio et al. (2000) report psychological findings that overarching identity helps to diminish hostility and prejudice as it also augments positive attitudes and cooperation among social units. In sum, the main peace-related variables tended to correlate positively with each other. This parallels the structural analysis of positive and negative factors by Liebovitch et al. (2019) who found three groupings of variables, with one being comprised of peace-related variables similar to those considered in the current study (i.e., shared identity, interconnectedness, a positive history of relationships, prosocial norms, transcendent or caring values, peace symbols, governance, 
and peace leaders, and additionally, peace education, peace vision, positive reciprocity, and positive goals).

With the partial exception of ethnocentrism, war variables also positively correlated with one another. All significant correlations between peace and war variables were negative, with peace versus war values and norms showing a very a strong negative correlation. Additionally, peace systems tend to have significantly stronger peace values and norms, whereas non-peace systems tend to have significantly stronger war values and norms.

Perhaps, once established, either war or peace orientations may stabilise among neighbouring societies. However, over time conditions of war among neighbours can be transformed into non-warring relationships, such as among the Swiss cantons after Switzerland was formed, Italian states and kingdoms after unification, or the tribes of Iroquoia after the creation of their confederacy (Archer, 2003; Fry, 2006; Sponsel, 2018). The Nordic countries transitioned "from a region rife with warfare to an area whose conflicts are 'non-wars' embracing diplomatic solutions" (Archer, 2003: p. 8).

An important topic for future research would be the investigation of which features found in peace systems have been key drivers of transformations over time from war to peace. The collection of longitudinal data, when available, on the nature of historical transformations would be necessary to address this topic. Some peace systems such as the ten Upper Xingu peoples, the Montagnais-Naskapi-East Main Cree, the Malaysian Orang Asli, and the Nigiri Plateau tribes were already in operation when early ethnographic information was gathered, so the historical roots of the non-warring intergroup relations probably will remain obscure. However, historical and ethnohistorical data do exist for some cases such as the formation of Switzerland, the United States, and the Iroquois confederacy. The findings of this study lead to several provisional observations that are ripe for further historical investigation.

First, it seems that a sense of overarching identity develops gradually over time, becoming, as found in our study, a maintaining feature of peace systems but not necessarily an early driver of peace. For example, it took time for an overarching Italian identity to emerge following unification (Cronin, 1999). Likewise, at the time of the US Constitutional Convention, people perceived themselves first-and-foremost as New Yorkers, North Carolinians, Virginians, and so on, not members of the United States as a whole (Hendrickson, 2003; Parent, 2011). This overarching US identity developed over time.

Second, our research suggests that security interdependence often drives historical transformations toward unity, cooperation, and peace. Parent (2011: p. 91) succinctly concludes that "Switzerland is a country because foreign threats forged it into one". Concerns about Austrian domination drove Italian integration (Cronin, 1999). Hendrickson (2003) makes a convincing case that concerns over external threats contributed substantially to the "peace pact" among the original 13 United States. As George Washington remarked, if Georgia, "with powerful tribes of Indians in its rear, \& the Spanish on its flank, do not incline to embrace a strong general Government, there must, I should think, be either wickedness, or insanity in their conduct" (Washington quoted in Parent, 2011: p. 45). In fact, Georgia was one of the first states to ratify the US Constitution. In sum, when the history is known, a recurring theme is that a common external threat is one factor that can facilitate the formation of a peace system. This leads us to raise the question by analogy whether common threats to humanity such as climate change, ecological collapse, or global pandemics could spur among global neighbours the type of unity, cooperation, and peaceful practices that are the hallmark of peace systems existing at other social levels (see Fig. 4).

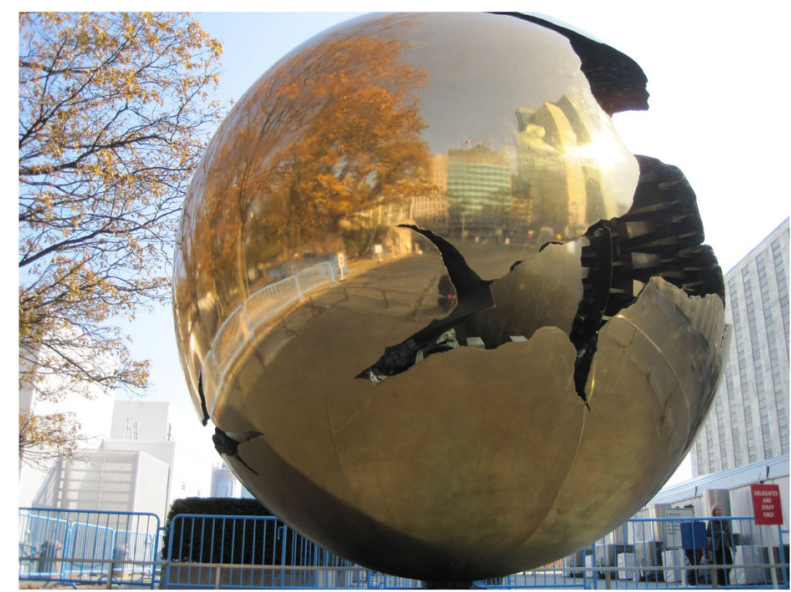

Fig. 4 A wounded planet is conveyed by Sphere within Sphere by Arnaldo Pomodoro, 1996, just outside the United Nations Headquarters in New York. Extant peace systems demonstrate the human capacities to create non-warring social systems and to solve common challenges through collaboration. An understanding of peace systems holds promise for facilitating cooperation and solidarity in addressing global pandemics, climate change, and ecosystem collapse. Reproduced with permission of Douglas P. Fry; copyright (c) Douglas P. Fry, all rights reserved.

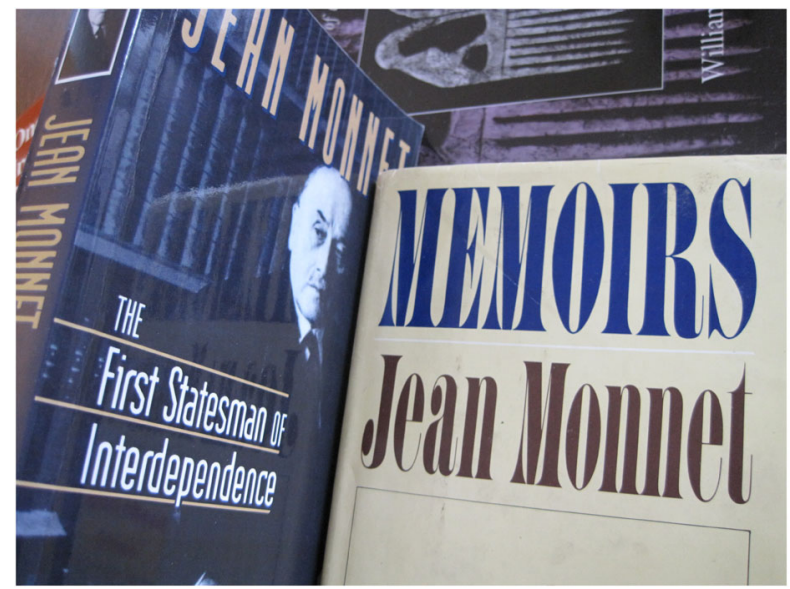

Fig. 5 Jean Monnet (1888-1979), avid promoter of European integration, epitomises the type of visionary peace leadership sometimes seen in peace systems that can unify hostile neighbours and guide them on a new path away from the scourge of war. Reproduced with permission of Douglas P. Fry; copyright (c) Douglas P. Fry, all rights reserved.

Third, another factor that may give initial impetus to the development of a peace system is visionary peace-focused leadership. Such leadership was clearly present at the founding of the United States among the Federalists as they pointed out the perils of anarchy and the benefits of unification (Hendrickson, 2003; Parent, 2011). The legendary peacemaker of the Iroquois, Deganawidah, advocated a new vision with peace and unity at its core and voiced the explicit goal of replacing chronic warfare with a confederation, the League of Peace. In a similar vein and driven by a vision of abolishing future wars in Europe, Jean Monnet (1978) and his colleagues conceptualised a new order with centralised, supranational institutions. Like Deganawidah, the peace leadership of Monnet and his contemporaries was critical in promoting a transformation in thinking and acting that successfully turned a continent away from war (Fry, 2012). Monnet not only gave the people and politicians of Europe a vision of peace, but also provided a plan on how to achieve the socio- 
political transformation from war to peace, which segues to our next observation (see Fig. 5).

We found that economic relationships and interdependencies exist to a greater degree in peace systems than in non-peace systems. Is economic interdependence an initial contributor to peace or does it come later as a reflection of established peace? Whereas a systematic assessment of this question deserves further historical research, the only clear case in our sample of economic interdependence being purposefully promoted in the name of peace is by the architects of the European Union. The European founders strove to make the economies of European countries progressively more integrated (Monnet, 1978). The first major step was the formation of the supranational European Coal and Steel Community, followed by the Common Market, and ultimately by a host of integrated economic measures and EU institutions. As a provisional generalisation however, it seems that economic interdependence more typically flourishes after peace systems come into being, rather than being intentionally developed at the onset as a path to peace. For example, prior to the formation of the Iroquois Confederacy, economic exchange among the warring groups was nil. Archaeology shows how trade among the member societies increased over time once the Great League of Peace was established. Regarding Italy, "political integration preceded economic integration" (Cronin, 1999: p. 76, emphasis in original). Similarly, prior to unification there was minimal commercial activity and no common currency among the original 13 US colonies-turned-states (Hendrickson, 2003). Indeed, after unification economic interdependence developed over time.

We raise three policy implications. First, our findings suggest that multiple factors are important in the dynamics of creating and maintaining peaceful social systems. Therefore, rather than looking for a single path, it may be more effective to take a multipronged approach to enhancing positive, collaborative relationships.

Second, non-warring norms and values deserve special mention because they are among the highest scoring of all the peace variables and correspondingly have high levels of importance for a peace system outcome as assessed by machine learning. Counter to presumptions that material factors predominate, peaceoriented values and normative principles may be critically important in the development of non-warring, prosocial intergroup relations.

Non-warring norms and values can become so established that war within the system becomes inconceivable. For example, the historically warring Swiss cantons, or belligerent Italian kingdoms, after they were amalgamated in the 1800s into Switzerland and Italy, respectively, came to perceive themselves as unified non-warring members of a common national society. Similarly, if disputing water rights, it is understood that Colorado and Kansas will meet in the courtroom rather than on the battlefield (Fry, 2006). Among the Nordic countries, Dutch provinces, and Iroquoian tribes, the war option became unthinkable as nonviolent norms evolved to govern transborder relations (Archer, 2003; Souillac, 2012, 2020).

Leaders may promote new norms and values that disavow war and promote peace. The Iroquois adopted peace as a core value, as chiefs dedicated themselves to "righteousness, justice, and peace" (Dennis, 1993: p. 87). They literally referred to their confederacy as the Great Peace or the League of Peace. They promoted norms in the League of Peace that emphasised respect for others, restraint against expressing hostility, consensus-based decision-making, and the promotion of the common good over solely parochial interests (Dennis, 1993). To reinforce values and norms for peace and unity, the meetings of the Intertribal Council always began with a recitation of the epic legend of how the prophet-peacemaker, Deganawidah, and his followers established the Great Peace (Dennis, 1993; Fenton, 1998).

In sum, values and norms constitute the principles and rules that circumscribe acceptable social action (Schirch, 2014; Souillac, 2012, 2020). Leaders can promote in word and deed-and societies can codify in laws and institutions-peace-promoting, anti-war values and norms. Non-warring values and norms can be enhanced and supported through cultural narratives, symbols, and rituals while also being built into institutions and legal structures. In the words of Jean Monnet (1978: pp. 304-5, 384) on creating peace, "Nothing is possible without men; nothing is lasting without institutions. ... The life of institutions is longer than that of men: if they are well built, they can accumulate and hand on the wisdom to succeeding generations."

Third, architects of peace may find it most profitable to focus on peace-related factors that are both important and changeable (Souillac, 2012, 2020). Whereas a positive history of interconnectedness-found via machine learning to be moderately important in peace systems-cannot be changed as the past has passed, interconnectedness in various other realms, such as trade, can be augmented through deliberate economic policies. As mentioned, an explicit strategy of economic integration was employed during European unification (Fry, 2012; Monnet, 1978), and economic exchange also appears in other peace systems such as the tribal societies of the Nilgiri Plateau and the Upper Xingu River basin (Gregor, 1994; Rivers, 1986). Overarching institutions can be created, often by applying known mechanisms of dispute resolution or decision-making at higher, transborder levels. Finally, returning to historical interconnectedness, narratives about past relationships also may be recontextualised to promote peace in the present and future (Souillac, 2012, 2020).

The promotion of peaceful interaction among societies is not merely valuable in-and-of-itself, but also can facilitate the regional and global cooperation necessary to address challenges to human survival and well-being that span borders. The United Nations Secretary-General, António Guterres, emphasises the need for international cooperation to address such global challenges as climate change and pandemics (Guterres, 2020). The nurturing of non-warring social systems may be corequisite with the international cooperation needed to address such interwoven global challenges as pandemics, species loss, nuclear proliferation, and climate change. The development of regional and global peace systems offers potential for addressing common transborder challenges.

\section{Data availability}

All data generated or analysed during this study are included in this published article in the Supplementary Information online data file.

Received: 2 August 2020; Accepted: 7 December 2020; Published online: 18 January 2021

\section{References}

Archer C (2003) Introduction. In: Archer C, Joenniemi P (eds) The Nordic peace. Ashgate, Hampshire, UK, pp. 1-23

Bellier I, Wilson T (2000) An anthropology of the European Union: building, imagining and experiencing the new Europe. Berg, Oxford, UK

Coleman PT, Deutsch M (eds) (2012) Psychological components of sustainable peace. Springer, New York, NY

Cronin B (1999) Community under anarchy. Columbia University Press, New York, NY

Dennis M (1993) Cultivating a landscape of peace. Cornell University Press, Ithaca, NY 
Dentan R (2004) Cautious, alert, polite, and elusive: the Semai of Central Peninsular Malaysia. In: Kemp G, Fry DP (eds) Keeping the peace. Routledge, New York, NY, pp. 167-184

Dovidio J, Gaertner S, Kafati G (2000) Group identity and intergroup relations: the common in-group identity model. Adv Group Process 17:1-35

Ember C, Ember M (2001) Cross-cultural research methods. Alta Mira, Lanham, $\mathrm{MD}$

Endicott KM (2017) Peaceful sociality: the causes of nonviolence among the Orang Asli of Malaysia. In: Ziegler Remme JH, Sillander K (eds) Human nature and social life. Cambridge University Press, Cambridge, pp. 97-109

Endicott KM, Endicott KL (2008) The headman was a woman. Waveland, Long Grove, IL

Fenton W (1998) The great law of the longhouse. University of Oklahoma Press, Norman, OK

Ferguson RB (2013) The prehistory of war and peace in Europe and the Near East. In: Fry DP (ed) War, peace, and human nature. Oxford University Press, Oxford, pp. 191-240

Fry DP (2006) The human potential for peace. Oxford University Press, Oxford

Fry DP (2009) Anthropological insights for creating nonwarring social systems. J Aggress Confl Peace Res 1:4-15

Fry DP (2012) Life without war. Science 336:879-884

Goldschmidt W (1994) Peacemaking and the institutions of peace in tribal society. In: Sponsel LE, Gregor T (eds) The anthropology of peace and nonviolence. Rienner, Boulder, CO, pp. 109-131

Gregor T (1990) Uneasy peace: intertribal relations in Brazil's Upper Xingu. In: Haas J (ed) The anthropology of war. Cambridge University Press, Cambridge, pp. 105-124

Gregor T (1994) Symbols and rituals of peace in Brazil's Upper Xingu. In: Sponsel LE, Gregor T eds The anthropology of peace and nonviolence. Rienner, Boulder, CO, pp. 241-257

Guterres A (2020) Global cooperation must adapt to meet biggest threat since Second World War, Secretary-General says on International Day, as COVID19 transcends borders. United Nations, Secretary-General, Statements and Messages, April 23, available at: https://www.un.org/press/en/2020/ sgsm20058.doc.htm

Haarh M (2020) Random number generator. Available at: https://www.random. org/

Haas J (1999) The origins of war and ethnic violence. In: Carman J, Harding A (eds) Ancient warfare. Sutton, Gloucestershire, UK, pp. 11-24

Hendrickson D (2003) Peace pact. University of Kansas, Lawrence

Hill S (2010) Europe's promise. University of California Press, Berkeley

Howell S (1989) 'To be angry is not to be human, but to be fearful is': Chewong concepts of human nature. In: Howell S, Willis R (eds) Societies at peace. Routledge, London, pp. 45-59

IBM (2019) SPSS, version 26.0, released 13 May

Ireland E (1986) Cerebral savage: the whiteman as symbol of cleverness and savagery in Waurá myth. In: Hill J (ed) Rethinking history and myth. University of Illinois Press, Urbana, pp. 158-173

Liebovitch LS, Coleman PT, Bechhofer A, Colon C, Donahue J, Eisenbach C, Guzmán-Vargas L, Jacobs D, Khan A, Li C, Maksumov D, Mucia J, Persaud M, Salimi M, Schweiger L, Wang, Q (2019) Complexity analysis of sustainable peace: mathematical models and data science measurements. N J Phys 21:073022

Monnet J (1978) Memoirs, trans by Mayne, R. Double Day, Garden City, NY

Montagu A (ed) (1978) Learning non-aggression. Oxford University Press, Oxford

Murdock G, White D (1969) Standard cross-cultural sample. Ethnology 8:329-369

Murdock G, White D (2006) Standard cross-cultural sample: online edition. UC Irvine, Social Dynamics and Complexity, Irvine, CA, https://escholarship.org/ uc/item/62c5c02n\#main Available online at

Nowak A, Bui-Wrzosinska L, Vallacher R, Coleman PT (2012) Sustainable peace: a dynamical systems perspective. In: Coleman PT, Deutsch M (eds) Psychological components of sustainable peace. Springer, New York, NY

Parent J (2011) Uniting states. Oxford University Press, Oxford

Pedregosa F, Varoquaux G, Gramfort A, Michel V, Thirion B, Grisel O, Blondel M, Prettenhofer P, Weiss R, Dubourg V, Vanderplas J, Passos A, Cournapeau D, Brucher M, Perrot M, Duchesnay É (2011) Scikit-learn: machine learning in python J Mach Learn Res 12:2825-2830. http://jmlr.csail.mit.edu/papers/v12/ pedregosal1a.html Available online

Raschka S, Mirjalili V (2017) Python machine learning: machine learning and deep learning with Python, scikit-learn, and TensorFlow, 3rd edn. Packt, Birmingham, UK
Rivers W (1986) The Todas. Rawat, Jaipur, India [originally published, 1906]

Rubin J, Pruitt D, Kim S (1994) Social conflict: escalation, stalemate, and settlement, 2nd edn. McGraw-Hill, New York, NY

Schirch L (2014) Ritual and symbol in peacebuilding. Kumarian, Boulder, CO

Souillac G (2012) A study in transborder ethics: justice, citizenship, and civility. Lang, Brussels

Souillac G (2020) Peace as integration: the modern era. In: Edsforth WR (ed) A cultural history of peace, 1920-Present, vol 6. Bloomberg, London, pp. $163-180$

Souillac G, Fry DP (2014) Indigenous lessons for conflict resolution. In: Coleman PT, Deutsch M, Marcus E eds The handbook of conflict resolution theory and practice. Jossey-Bass, San Francisco, CA, pp. 604-622

Souillac G, Fry DP (2015) The philosophical anthropology of interculturality: a vehicle for creating inclusive identities and positive peace. Thémata, Revista de Filosofía 52:31-39

Sponsel LE (2018) One anthropologist's answer to Glenn D Paige's question challenging peace studies. J Peace Educ 15:267-287

Staab A (2008) The European Union explained. Indiana University Press, Bloomington, IN

Walker A (1986) The Toda of South India. Hundustan, Delhi, India

White D (1989) Focused ethnographic bibliography: standard cross-cultural sample. Behav Sci Res 23:1-145

Wilson E (2001) On human nature. In: Barash DP (ed.) Understanding violence. Allyn and Bacon, Boston

Wright Q (1942) A study of war. University of Chicago Press, Chicago

Yiu T (2019) Understanding random forest: how the algorithm works and why it is so effective. Towards Data Science, June 12. Available online:https:// towardsdatascience.com/understanding-random-forest-58381e $0602 \mathrm{~d} 2$

\section{Acknowledgements}

We thank Benjamin Maddox, David Gilchrist, and Michelle Bird for facilitating the project in various ways and Dr. Jeff Labban for analytical consultation and advice. Some of the ethnographic data collected through the National Science Foundation research grant "A Cross-Cultural Study of Conflict Prevention, Resolution, and Reconciliation" (0313670), PI Douglas P. Fry, were used in this project. The Advanced Consortium on Cooperation, Conflict, and Complexity (AC4) at Columbia University, directed by Peter T. Coleman, provided funding to hire research assistants, as did the University of Alabama at Birmingham through start-up funds for Douglas P. Fry.

\section{Competing interests}

The authors declare no competing interests.

\section{Additional information}

Supplementary information is available for this paper at https://doi.org/10.1057/s41599020-00692-8.

Correspondence and requests for materials should be addressed to D.P.F

Reprints and permission information is available at http://www.nature.com/reprints

Publisher's note Springer Nature remains neutral with regard to jurisdictional claims in published maps and institutional affiliations.

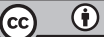

Open Access This article is licensed under a Creative Commons Attribution 4.0 International License, which permits use, sharing adaptation, distribution and reproduction in any medium or format, as long as you give appropriate credit to the original author(s) and the source, provide a link to the Creative Commons license, and indicate if changes were made. The images or other third party material in this article are included in the article's Creative Commons license, unles indicated otherwise in a credit line to the material. If material is not included in the article's Creative Commons license and your intended use is not permitted by statutory regulation or exceeds the permitted use, you will need to obtain permission directly from the copyright holder. To view a copy of this license, visit http://creativecommons.org/ licenses/by/4.0/

(c) The Author(s) 2021 